\title{
Geohistória da Mundialização: o caso da expansão do Islã na África a partir de Ibn Khaldun ${ }^{1}$
}

\section{Geohistory of Globalization: the case of the spread of Islam in Africa through na Approach of Ibn Khaldun}

\author{
Luiz Pereira \\ Pontifícia Universidade Católica de Minas Gerais \\ luizfdpereira@gmail.com \\ Rodrigo Correa Teixeira \\ Pontifícia Universidade Católica de Minas Gerais \\ rteixeira@pucminas.br \\ Joelton Lima \\ Pontifícia Universidade Católica de Minas Gerais \\ joeltonlima2@yahoo.com.br
}

\section{Resumo}

Este artigo propõe uma reflexão sobre Ibn Khaldun e o mito da "invasão árabe" no Norte da África. Por meio de uma análise da obra de Ibn Khaldun e à luz da crítica de Edward Said sobre um pensamento ocidental acerca do oriente (Orientalismo), questiona-se uma narrativa eurocêntrica na qual os árabes não conseguem gerar conhecimento, apenas transportá-lo. Busca-se, portanto, uma contribuição para estudos sobre o Sul Global.

Palavras-chave: Ibn Khaldun; África; Islã; História Global; Geohistória.

\begin{abstract}
This article proposes a reflection on Ibn Khaldun and the supposed myth of the "Arab invasion" in North Africa. Through an analysis of Ibn Khaldun's work and in the light of Edward Said's critique of a Western thought concerning the East (Orientalism), the authors criticize a Eurocentric narrative which assume that Arabs cannot generate knowledge, only propagate it. Therefore, it aims to provide a contribution to studies regarding the Global South.
\end{abstract}

Keywords: Ibn Khaldun. Africa. Islam. Global History. Geohistory.

\section{INTRODUÇÃO}

Este artigo desenvolve uma um caminho reflexivo acerca das leituras contra hegemônicas da obra de Ibn Khaldun, destacando a diversidade da produção do pensador e as múltiplas leituras que sua obra tem proporcionado.

A partir do surgimento do Islã no século VII, a historiografia árabe acompanhou a sua expansão mercantil e religiosa, aumentando e intensificando seus domínios. As primeiras histórias

\footnotetext{
${ }^{1} \mathrm{O}$ presente trabalho foi realizado com apoio da Coordenação de Aperfeiçoamento de Pessoal de Nível Superior Brasil (CAPES) - Código de Financiamento 001
} 
globais árabes nasceram da necessidade de legitimar o Islã como crença universal e verdadeira, por isso, neste momento, a historiografia era tributária metodologicamente da exegese religiosa. No entanto, os árabes se interessavam cada vez pelos povos subjugados no Oriente Próximo, Norte da África e Espanha. O mosaico cultural surgido pela confluência entre muçulmanos, judeus e cristãos contribuíram para aumentar o interesse dos historiadores árabes quanto à história de outros povos.

\section{DA GEOPOLÍTICA DO CONHECIMENTO: IBN KHALDUN}

Partindo das discussões em torno da alteridade, considerara-se o olhar eurocêntrico sobre o mundo árabe e islâmico como tendo constituído o chamado Orientalismo (SAID, 2007), um ramo de estudos acadêmicos surgido em universidades da Europa para o estudo do chamado "Oriente". Esta abordagem atingiu de forma contundente também a visão sobre a África. Como contraponto a isto, traz-se um autor clássico, mas que oferece uma perspectiva contra hegemônica: Ibn Khaldun.

Ibn Khaldun, durante o século XIV, construiu uma perspectiva privilegiada sobre o Magreb (norte da África), fornecendo aos pesquisadores contemporâneos depoimentos e análises de refinada qualidade sobre a cultura, as relações sociais e dinâmica política das sociedades desta região africana.

Ao lado de Idrisi e Ibn Batuta, Ibn Khaldun é, certamente, um dos pensadores dos séculos passados mais estudados do mundo árabe-muçulmano na atualidade. Ibn Khaldun escreveu a Muqaddimah e os livros seguintes, convencido da necessidade de deixar para a posteridade um quadro do conjunto da civilização árabe-muçulmana. É considerada há mais de um século uma obra clássica do pensamento histórico, a primeira tentativa conhecida de criar uma ciência das sociedades independente da Teologia e da Filosofia. Estudando o norte da África e os impérios ali formados ao longo dos séculos, Ibn Khaldun concebeu uma filosofia da história, uma sociologia e uma geopolítica com grande sensibilidade crítica. Afastando-se da tradição, Ibn Khaldun chegava aos limites possíveis, naquele contexto histórico, da independência de pensamento (SENKO, 2011 e 2012; KHALDUN, 1958 - 1960).

Ibn Khaldun nasceu em Túnis, em 1332, e morreu no Cairo, em 1406. A primeira parte de sua vida foi dedicada à política, num período particularmente agitado na história da África do Norte.

As guerras e lutas internas que caracterizaram todo o século XIV provocaram a ruína de muitos centros urbanos e o empobrecimento das finanças públicas no mundo islâmico. Mas, no Magreb nesse século se consolida uma identidade cultural, com características singulares dentro do mundo islâmico. Afastado durante longos anos da sua terra natal, à qual nunca regressou depois de partir num autoexílio, Ibn Khaldun cultivou até o fím da vida as raízes magrebinas e, sempre que 
possível, mostrou orgulho em pertencer ao entorno geopolítico e cultural forjado sob a influência de Al-Andalus, terra de seus antepassados (BISSIO, 2012).

Ibn Khaldun foi testemunho de uma época de transição, na qual os países muçulmanos trataram de preservar o conhecimento do período clássico nos planos jurídico e religioso, assim como nos domínios científico, artístico e literário. Nesse momento histórico, o Islã estava mais voltado para o passado do que para o futuro (BISSIO, 2012).

No período compreendido entre os séculos XIII e XIV as fronteiras do mundo muçulmano mudaram substancialmente. Na área oriental, uma dinastia mongol, vinda da Ásia Oriental, conquistou o Irã e o Iraque, e colocou um fim ao Califado Abássida em Bagdá, em 1258 (HOURANI, 2001, p. 100). Convertidos ao Islã, os mongóis foram freados na sua tentativa de marchar para o oeste pelo exército egípcio formado por escravos militares (mamelucos). Oriunda do Cáucaso e da Ásia Central, a elite militar mameluca governou o Egito por mais de dois séculos (1250-1517); também governou a Síria a partir de 1260, e controlou as cidades santas da Península Arábica. Na parte ocidental, o declínio da Dinastia Almôada deu lugar a vários estados; no Magreb, entre eles, o dos marínidas no Marrocos (1196-1465) e o dos hafsidas, na Tunísia (1228-1574) (HOURANI, 2001, p. 101). A maior parte de Al-Andalus, a Península Ibérica muçulmana, de onde provinha a família dos Beni Khaldun, caiu nas mãos dos reinos cristãos do Norte e, em meados do século XIV, do antigo esplendor muçulmano só restava o reino de Granada, no sul (BISSIO, 2012).

Em sua biografia há um episódio notável que foi o seu encontro entre maior líder guerreiro do mundo à época, Timur-i-Lenk (em português Tamerlão), no final do século XIV, nas portas de Damasco (hoje capital da Síria e antes sede do Califado Árabe). O guerreiro mongol manda chamar Khaldun, impressionado com a sua fama, e os dois estabelecem intenso diálogo. Tamerlão faz perguntas a Khaldun, interrogando-o sobre temas da época e da história do norte da África. Por esse debate, o líder mongol manda conduzir em segurança Khaldun além das portas de Damasco (KHALDUN, 1958-1960, vol. I, p. 553).

Ibn Khaldun teve oportunidade de conhecer e morar nos grandes centros de poder, que também eram os polos de efervescência cultural, notadamente o Cairo, sob controle mameluco, onde exerceu a função de cádi (juiz) e lecionou na Universidade de Al-Azhar (BISSIO, 2012).

Embora sua família tenha emigrado de Sevilha quando da conquista cristã, chegando ao Norte da África por volta de 1235, era originário de Hadramaut, logo, sua origem mais provável era árabe (como ele mesmo atestava). Aos 20 anos, tornou-se secretário do sultão² de Fez, no Marrocos - e foi feliz em escapar com apenas dois anos de prisão quando perdeu o favor do sultão. Mais tarde, entrou a serviço do rei de Granada - e acabou novamente em situação de dificuldade. Em 1375, cansado e decepcionado, mas amadurecido, recolheu-se com sua família no castelo de Kalaat

${ }^{2}$ Sultão “quer dizer mais ou menos 'detentor do poder"” (HOURANI, 2001, p. 100). 
Ibn Salama, perto de Orã e, por quatro anos inteiros, trabalhou em seus Prolegômenos Muqaddimah.

Entre as contribuições que desenvolve nessa obra, Ibn Khaldun argumenta que os fenômenos sociais parecem obedecer a leis que, conquanto não sejam tão absolutas quanto as que governam os fenômenos naturais, são suficientemente constantes para fazer os acontecimentos sociais seguir seus padrões e sequências populares e bem definidos. Essas leis operam sobre as massas e não podem ser influenciadas significativamente por indivíduos isolados. As tentativas de um reformador para rejuvenescer um Estado corrupto, por exemplo, dificilmente conseguem êxito, porque os esforços individuais são esmagados pelo poder irresistível das forças sociais. As mesmas leis operam nas sociedades que têm o mesmo tipo de estrutura, embora essas sociedades estejam separadas no espaço e no tempo.

Quando Ibn Khaldun assume a tarefa de sistematizar todo seu conhecimento e sua experiência em um livro - missão que se impõe durante quatro anos de reclusão em uma fortaleza do interior da Argélia, como destaca na sua autobiografia - ele busca dar uma resposta radical ao desafio vivido pelo Islã: fazia-se necessária uma nova ciência, que fornecesse leis universais capazes de explicar o funcionamento das sociedades humanas. É essa ciência que ele pretende fundar com sua mais importante obra, a Muqaddimah, pela qual passou à posteridade. O esforço não foi em vão: esse livro - na verdade os Prolegómenos a uma História Universal em vários volumes - é considerado há mais de um século uma obra clássica do pensamento histórico, a primeira tentativa conhecida de criar uma ciência das sociedades independente da teologia e da filosofia. Afastando-se da tradição, Ibn Khaldun chegava aos limites possíveis, no contexto histórico em que se encontrava, da independência de pensamento (BISSIO, 2012).

Nesse contexto, destaca-se uma das vertentes primitivas do Islã, o zelo pela produção científica além do câmbio de conhecimentos pela interação entre povos.

Com uma vida pública de atividades nas cortes turbulentas da África do Norte e Andaluzia, Ibn Khaldun participou dos altos e baixos de vários regimes aristocráticos. Se por um lado sua vida pública reflete a instabilidade da região, por outro, é no registro de uma teorização de sua experiência pessoal que ele fala de questões que alcançam um além do imediatismo dos acontecimentos (SENKO, 2011 e 2012; KHALDUN, 1958 - 1960).

Se o mundo islâmico apresentava no século XIV um cenário convulsionado, com a economia e a política em fase crítica, a instabilidade nesses terrenos não conseguiu destruir a unidade cultural; ao contrário, ela tornava-se mais profunda à medida que novos contingentes humanos se convertiam à fé muçulmana. De fato, a essa altura, seguindo o vale do rio Nilo e a costa oriental africana, a religião islâmica continuava a sua expansão, ao longo das rotas comerciais, levada muitas vezes pelos próprios mercadores e indiferente aos conflitos políticos e militares. $\mathrm{O}$ 
avanço continuou pelo Sahel e pela margem sul do deserto do Saara, avançando em direção ao interior da África (BISSIO, 2012). Chama especial atenção de Khaldun a estagnação e o início de decadência das sociedades muçulmanas no norte da África, exatamente quando o Islã se manifestava com maior vigor nos grandes Estados sudaneses e se tornava também mais ativo nas Cidades-Estado swahili.

Ibn Khaldun não observa a conflitiva situação do Magreb e do mundo islâmico com a perspectiva de um progresso linear, mas no contexto de uma evolução cíclica: uma fase negativa que põe fim a um ciclo do poder será seguida necessariamente de uma fase positiva, de reconstrução. Assim, o século XIV se apresentaria como um período de espera de um novo ciclo da civilização (umram) sob a égide de um novo povo - que ele identifica, perto do fim da sua vida, com os turcos. É alicerçado nessa concepção da história que Ibn Khaldun, apesar das dificuldades e desafios desse momento - incluindo os horrores da devastadora peste negra, que vitimou seus pais e seus primeiros mestres e dizimou a população do mundo árabe-islâmico tanto quanto a da Cristandade - não desenvolve uma visão pessimista. Na verdade, ele acredita que a ordem humana, uma vez atingida à maturidade, é essencialmente estável, quase imutável. E, na sua avaliação, essa maturidade tinha sido atingida pela civilização islâmica (BISSIO, 2012).

Ibn Khaldun define a civilização humana como sendo formada por indivíduos livres, autônomos e iguais e constituída por dois polos em equilíbrio, a civilização rural (umram badawi) e a civilização urbana (umram hadari), sendo ambas complementarias. Para chegar a essa conclusão toma como referência de análise as formas utilizadas pelo homem para assegurar sua subsistência e analisa, ainda, a cidade, acompanhando as suas mudanças ao longo do tempo e as particularidades culturais e regionais no uso e organização do espaço (BISSIO, 2012).

Isso não significa que não houvesse ainda a possibilidade de aperfeiçoamentos. Mas, Ibn Khaldun considera, de um lado, que as ciências e as técnicas, com a herança acumulada dos gregos, dos persas e dos árabes, já atingiram o nível máximo do potencial do espírito humano; pensa, também, que com o Islã a religião chegara ao seu mais alto grau de perfeição (BISSIO, 2012).

Referencie-se que Ibn Khaldun coloca o ponto de mutação cultural na história da humanidade na urbanização, fruto muitas vezes de conflitos e fricções inter étnicas, condição necessária, na sua análise - mesmo que não suficiente, por razões que desenvolve ao estudar a decadência dos impérios -, para o desenvolvimento da civilização. A partir daí, o historiador estuda a influência que o espaço físico, social, institucional e econômico tem na história e chega à conclusão que o meio geográfico cria possibilidades importantes para a vida dos grupos sociais, mas não exerce um determinismo rigoroso (BISSIO, 2012).

Ibn Khaldun percebe o processo histórico como inscrito num ciclo alternante entre duas formas básicas de organização social, que são as seguintes: beduína (nômade) ou sedentária. Este 
movimento pendular não é hierarquizado, mas complementar. Entretanto, a despeito dos problemas desta teorização, Ibn Khaldun problematiza o desenvolvimento da sociedade, ao dedicar-se a escrever uma história geral das dinastias do Magreb:

\begin{abstract}
A primeira parte dessa obra, o Muqaddima (Prolegômenos), continua atraindo a atenção até hoje. Nele, Ibn Khaldun tentou explicar a ascensão e queda das dinastias de um modo que servisse de padrão para aferir a credibilidade das narrativas históricas. Achava que a forma mais simples e antiga da sociedade humana era a do povo das estepes e montanhas, cultivando a terra ou criando gado, e seguindo líderes que não tinham poder de coerção organizado. Esse povo tinha certa bondade e energia naturais, mas não podia por si mesmo criar governos estáveis, cidades ou grande cultura. Para que isso fosse possível, era preciso um governante com autoridade exclusiva, o qual só se estabeleceria se pudesse formar e controlar um grupo de seguidores dotado de asabiyya, ou seja, de um espírito coorporativo voltado para obtenção e manutenção do poder. O ideal seria que os membros desse grupo fossem escolhidos entre os enérgicos homens da estepe ou da montanha; o grupo seria mantido junto pelo senso de ancestralidade comum, real ou fictícia, ou por laços de dependência, e reforçado pela aceitação de uma religião comum. Um governante com um grupo forte e coerente de seguidores podia fundar uma dinastia; quando seu governo estivesse estável, surgiriam cidades populosas estáveis, e nelas haveria ofícios especializados, estilos de vida luxuosos e alta cultura. Toda dinastia, porém, trazia em si as sementes de seu declínio; seria enfraquecida pela tirania, extravagância e perda das qualidades de comando. O poder de fato passaria do governante para membros de seu próprio grupo, porém mais cedo ou mais tarde a dinastia seria substituída por outra formada de modo semelhante (HOURANI, 2001, p. 16).
\end{abstract}

Na sua obra, Ibn Khaldun define a civilização humana como sendo formada por indivíduos livres, autônomos e iguais e constituída por dois polos em equilíbrio, a civilização rural e a civilização urbana, sendo ambas complementarias. Para chegar a essa conclusão toma como referência de análise as formas utilizadas pelo homem para assegurar sua subsistência e analisa, ainda, a cidade, acompanhando as suas mudanças ao longo do tempo e as particularidades culturais e regionais no uso e organização do espaço (SENKO, 2011 e 2012; KHALDUN, 1958 - 1960).

Para ele os nômades eram guerreiros ou estavam mais bem preparados para a guerra do que as populações urbanas ou agrícolas. Assim, “[...] as aptidões belicosas do conjunto das populações fortaleceram as estruturas tribais, impedindo que os chefes guerreiros pudessem ampliar consideravelmente sua autoridade, o que poderia ser feito sobre uma população desarmada"(LACOSTE, 1991, p. 31-32).

Ibn Khaldun foi o primeiro intelectual árabe que estudou de forma consistente esse fenômeno, em especial no norte da África, dos povos nômades do deserto (em especial beduínos) e construiu uma teoria de ciclos de poder, onde os que eram nômades transformam em sedentários e posteriormente acabam vencidos pelos novos nômades que tomam as cidades e repetem esse ciclo. É o que alguns chamam de sociologia da beduinidade (BISSIO, 2012; SENKO, 2011 e 2012; KHALDUN, 1958 - 1960).

O movimento cíclico-histórico da sociedade poderia ser acompanhado pelo modelo das quatro gerações proposto pelo filósofo, no qual a corrupção, provavelmente entendida como o afastamento das virtudes daquele que conquistou a glória, marca o processo histórico de forma 
previsível nos meandros da sucessão da suserania.

Talvez por ser de Túnis, atual Tunísia, sua de sua formação inicial nas escolas de jurisprudência e a formação religiosa de sua família (Madrassas, "casa de estudos"), o colaborou nas viagens pelo vasto mundo mediterrâneo.

Sua obra mais relevante é a Muqaddimah, os Prolegômenos ${ }^{3}$ fruto de suas memória e observações dos sultanatos em pleno século XIV:

Na sua filosofia da história, por exemplo, propôs um método rígido de separação entre a realidade e a ficção. Além disso, Ibn Khaldun nos legou uma explicação sobre as leis universais que regulam as sociedades no tempo. Um dos conceitos khaldunianos mais importante na Muqaddimah é aassabiya que é definida como o espírito de grupo. (LEME, 2019, p. 38)

Esse espírito de grupo (aassabiya) foi analisado por Ibn Khaldun, no contexto políticoreligioso como algo decisivo na sociedade daquele tempo. Pode-se considerar uma categoria interpretativa aplicável às sociedades contemporâneas a partir dos aspectos de unicidade dos sistemas sociais. Ibn Khaldun apresenta a noção de aassabiya expondo a perspectiva de unidade muçulmana - nós e eles - ou sociedade de dentro, os fiéis, e a sociedade de fora, os incrédulos. Também diferencia as sociedades nômades e as sociedades sedentárias.

Produzindo sua obra em meio a inúmeros, turbulentos e controversos conflitos políticos, sobretudo envolvendo a dinastia dos Hafsidas (1228 -1574) e a dinastia dos Marínidas (1196 1465),

Ibn Khaldun serviu ambas as dinastias e se envolveu nos atritos com os Banu Hilal, tribo magrebina. Num sentido macro, a política norte africana estava sendo pressionada pelos turcos seljúcidas advindos do ambiente asiático, pelo avanço dos mongóis e pelos interesses de expansão política dos. Sobrevivente, Ibn Khaldun foi capaz de negociar no sentido de seus interesses e conseguiu - visando continuar com o trabalho intelectual - manter cargos sempre próximos ao poder, sejam eles de jurisprudente ou de "diplomata" (LEME, 2019, p. $39)$.

A diplomacia exercida por Ibn Khaldun possibilitou-o transitar por todo norte da África e em muitos espaços do Mundo Mediterrâneo. Os benefícios de tal trânsito, também de ter sido preso e depois liberto numa mudança de governo, podem ser identificados em tudo que sobrou de seus registros amplamente utilizados pela comunidade acadêmica, suas diferentes funções, sempre próximas à administração.

A habilidade em se modificar profissionalmente mantendo seu posicionamento, pode ser considerada uma marca de Ibn Khaldun. Quando o morre o sultão que o havia libertado e reconduzido ao conselho administrativo, ele torna-se professor em Bujaya - ao leste da Tunísiafugindo das pressões políticas, mas mantendo-se próximo as notícias do reino:

\footnotetext{
${ }^{3}$ Divididos em três tomos (I, II e III) esses Prolegômenos descrevem a sociedade muçulmana em seus diferentes contextos políticos, sociais e de interação desse grupos com os diferentes em vários espaços africanos e europeus.
} 
Daí passou a ser mestre da mesquita de Bujaya (norte de África), mas tão logo deixou de lecionar para trabalhar com o senhor de Tlemcen, Abu Hammu. Khaldun ficou responsável por registrar e cobrar os impostos do reino de Tlemcen, além de ser o hajib (aquele que mantém a harmonia dentro da sociedade islâmica). Essa posição de cobrador de impostos não era do agrado de Khaldun e ele se retirou para um retiro de meditação, depois disso retornou para servir o novo sultão marínida, Abd-al-Aziz (LEME, 2019, p. 40).

Quando esteve em Castela, tornou-se próximo ao rei Pedro I, o Cruel, filho de Afonso IV. Como prova de sua aptidão política, podemos ressaltar que foi Khaldun a conseguir por parte desse Rei a assinatura de um tratado de paz que colocaria fim à rivalidade entre os povos da Andaluzia e de Castela. Mesmo com essas influências, recusou ser conselheiro real voltando a funções antigas retomando suas funções em 1370(LEME, 2019, p. 40).

A biografia escrita de Ibn Khaldun redigida a partir desse contexto, e depois as considerações de sua História Mundial, ganha brilho e pompa ao se deslocar para o Cairo onde foi recebido com honrarias para lecionar na Universidade de Al-Azhar. (LEME, 2019, p. 40).

Há de se perceber que numa estrutura universitária podendo lecionar e ser concomitantemente juiz, sua vida social mantém-se agitada. Apesar de distante das polêmicas, sua posição social lhe garante um volume desigual de informações passivas de análise, organização e detida explicação (LEME, 2019, p. 40).

No bojo das contribuições dadas pelos escritores e pensadores norte africano desse período, ressaltando Ibn Khaldun como maior expoente desse processo, pode-se apresentar como uma das maiores contribuições a associação entre diferentes disciplinas que possibilitaram não só a estruturação futura das mesmas, como já em seus escritos a possibilidade de lançar luz ao futuro observando de maneira multiangular as diferentes feições da sociedade:

Sua grande preocupação com possibilitar uma metodologia inovadora fez com que ele aliasse isso com sua filosofia da história a qual buscava sentido no movimento dos acontecimentos sociais. Além de tentar compreender o sentido da história no passado Khaldun ao mesmo tempo tentava predizer ações do futuro possível. Através da ideia de razão universal que rege a sociedade poderia ser fundada a civilização (LEME, 2019, p. 41).

A Umma expressa em Khaldun constitui a civilização onde os fiéis podem, e estão vinculados uns aos outros, por laços maiores de compromisso e identificação. Entremeando todos os aspectos da vida em cidade e dos efeitos dessa "civilização" para além dos diferentes níveis de cultura e proximidade com a organização coletiva. Com esse pensador, o universo ${ }^{4}$ podia ser identificado como diferentes níveis de sociedade onde os diferentes grupos interligados por forças de pertença e coesão interagem aproximando-se ou distanciando-se por forças controláveis pelo governo. Para esse pensador também, a cultura e, sobretudo, as artes tende a declinar e perecer à medida que as cidades declinam em sua estrutura organizacional.

\footnotetext{
${ }^{4}$ A dita cultura universal corresponde aos escritos em busca de uma visão de totalidade da sociedade muçulmana da época.
} 
$\mathrm{Na}$ lógica khalduniana ainda serão os descendentes do soberano conquistador que vão desejar a luxuosidade extrema. E será nesse momento que a vida luxuosa na cidade e sem memória de qualquer sentido de assabiya que esse poder entrará em decadência. Ibn Khaldun apontou isso tanto para as civilizações mais antigas e suas conhecidas como a egípcia, a grega, a romana, os árabes peninsulares, magrebinos e andaluzes quanto os berberes. Ele chama a atenção para mais um motivo de decadência seja de uma civilização ou de apenas uma tribo, a presença de mercenários ao lado dos homens de armas locais. As ambições dos mercenários não têm nada a ver com os desejos identitários e de conquista dos homens de armas dos sultões ou califas (LEME, 2019, p.46).

Foi Ibn Khaldun que apresentou as diferentes possibilidades do fracasso das cidades da época, e as diferentes organizações. Para o mesmo, a corrupção inerente aos homens é o ponto de ruptura do tecido organizacional e das possibilidades de evolução social.

Para o pensador a assabiya, esse espírito de coletividade e integração social, atravessa a todos sejam os citadinos fixados, sejam nômades ou quaisquer outros grupos (LEME, 2019, p.46).

Assim retomamos para além da discussão das fronteiras suas fricções e volatilidades para ressaltar o quanto essa identidade social foi evidenciada por Ibn Khaldun. Nesse contexto, observemos os preceitos que guiavam os grupos mais próximos de Meca, Túnis e Cairo e como esse espírito de unidade arrefece quando se chega ao norte do mundo islâmico (Península Ibérica). Existe assim uma sobreposição conceitual entre assabiyae a força de coesão do credo no conjunto dos muçulmanos (LEME, 2019, p.47).

Ibn apresenta a Peste Negra assolando uma grande parte da população europeia. Também a grande Umma sofreram com a peste negra, tanto os berberes, quanto a sociedade urbana do norte de África e os ibéricos, que foram particularmente atingidos por essa terrível epidemia (LEME, 2019, p.47-49).

Ressaltamos que Ibn Khaldun enfatiza sua inquietação da fuga e redução do volume de intelectuais nesse contexto, assim como também o enfraquecimento de grupos de estudo e discussão. Esses assim como outros aspectos possibilitam centenas de outros estudos, e um novo volume de investigações em torno deste que é um dos principais pensadores da sociedade muçulmana e africana deste o anúncio do Profeta (LEME, 2019, p.47-49).

Ibn Khaldun não se limitava à narração ou a deixar em abertos às questões que lhe eram apresentadas. Ele desejava ir mais adiante. E fazia uma crítica importante sobre os historiadores, que vale desde os gregos antigos até o século XVIII: o de não distinguir a História Militar e Política da Evolução Social-Econômica (LACOSTE, 1991, p. 148). Especificamente falando do Mundo Árabe, a História estava inserida dentro das "Ciências Árabes", onde estavam a Gramática, a Poesia, a Jurisprudência Religiosa e a Retórica (LACOSTE, 1991, p. 141).

Na concepção de Lacoste (1991) há uma visão racionalista da Filosofia de Khaldun as 
questões religiosas do Islã se sobrepõem às relações econômicas e sociais que ele mesmo analisa ${ }^{5}$.

Tendo sido de todos os seus contemporâneos o historiador que foi mais longe na sua independência de pensamento, Ibn Khaldun mergulhou na análise do funcionamento da sociedade humana, no estudo das transformações sociais nos períodos de longa duração e enfatizou a necessidade de definir uma metodologia específica para o estudo dos fatos históricos, incluindo aí um critério de escolha dos documentos. Nesse sentido, a sua obra foi extremamente original e não fez escola nem deixou seguidores (BISSIO, 2012).

\section{IBN KHALDUN, ORIENTALISMO E O EUROCENTRISMO}

Se a obra de Ibn Khaldun é um marco da civilização muçulmana medieval, com o processo de europeização após 1500, o discurso de inferiorização do Oriente Médio e do Magreb (norte da África) foi se construindo de forma contundente, assim a obra de Edward Said (2007), Orientalismo, denuncia em estilo de crítica literária a imaginação geopolítica eurocêntrica aplicada à região.

Boaventura de Sousa Santos (2006, p.182-185) já salientara que o Oriente foi sempre o espaço da alteridade: o Ocidente não existe fora do contraste com o não-Ocidente, seja este visto como civilização alternativa, como centro da história, seja como ameaça, seja como recurso. Ou seja, o espaço da alteridade é o espaço, também, da descrição diabolizada do outro enquanto outro, da redução maniqueísta entre bem e mal, entre civilização e barbárie. Mas, ao mesmo tempo, há a descrição do exótico, e é por isso que o Oriente somente pode ser admirado pela opulência das cortes imperiais, pelas mil e uma noites, pela sensualidade. Apesar de ser fundamentalmente visto como temível e temido, o Oriente também é visto como recurso, como um imenso mercado a explorar, seja pelo número de habitantes, seja pela dependência ocidental dos recursos (a importância geoestratégica do Oriente Médio e do Golfo Pérsico fala por si mesma, bem como as invasões de Iraque e Afeganistão). ${ }^{6}$

A concepção do não-Ocidente visto como o Oriente foi, sem dúvida, o orientalismo. Segundo Edward Said (2007), orientalismo é a concepção do Oriente que domina nas Ciências Sociais e nas Humanidades, a partir do final do século XVIII, baseada nos seguintes pontos principais: uma distinção total entre "nós" ocidentais e "eles" orientais; a superioridade do Ocidente

\footnotetext{
${ }^{5}$ Ibn Khaldun é inovador. Embora, coloque a dimensão mundana como imperfeita em contraste com o mundo divino, tido como perfeito, busca explicações empíricas e desenvolve toda uma ciência (LACOSTE, 1991, p. 141-142 e 163).

${ }^{6}$ Boaventura de Sousa Santos (2006, p. 185) ainda observa que um Ocidente sitiado e altamente vulnerável tende a ampliar o tamanho do Oriente, diminuindo seu próprio tamanho, acarretando a perversão de constituição de Orientes dentro do Ocidente: "Foi este o significado da Guerra de Kosovo: o Ocidente eslavo transformado numa forma de despotismo oriental. Foi por isso que os kosovares, para estarem do 'lado certo' da história, não puderam ser islâmicos durante o conflito. Tiveram que ser apenas minorias étnicas".
} 
desenvolvido, racional e humano, contra posta ao Oriente aberrante, inferior, subdesenvolvido, despótico; o Ocidente é dinâmico, diverso, passível de autotransformação e auto definição, ao passo que o Oriente é estático, eterno, uniforme, incapaz de auto representação; e, por fim, o Oriente é temível e deve ser controlado pelo Ocidente, por meio de guerra, invasão, colonização, "pacificação" etc. Ou seja, o orientalismo estudava o Islã e as outras civilizações a partir das ideias europeias de Deus, homem, natureza, sociedade, ciência e história e, em consequência, descobria que as culturas e civilizações não-ocidentais eram inferiores e estavam atrasadas e, tal qual um espelho, codificava os desejos ocidentais e os transformava em disciplinas acadêmicas e depois projetava seus desejos sobre seu estudo do Oriente.

A crítica que se faz, em parte, à concepção de Said e que Walter Mignolo (2003, p. 82) explicita é que "não pode haver um Oriente, como "outro", sem o Ocidente como "o mesmo", o ocidentalismo era a figura geopolítica que constelava o imaginário do sistema mundial colonial/moderno. Como tal, era também a condição da emergência do orientalismo". E as Américas, assim, não são diferentes da Europa (como o são Ásia e África), mas sim a sua continuação. Consequentemente, não existe modernidade sem a colonialidade, mesmo que existam livros sobre colonialismo e outros sobre modernidade (como entidades separadas que não se imbricam, nem interagem), mesmo quando se afirmam que a modernidade é uma questão europeia, e a colonialidade algo que ocorre fora da Europa. Veja-se, por exemplo, que a Argélia dificilmente será “incluída como parte da história nacional francesa, apesar do fato de que uma história da Argélia, como nação, não pode ignorar a França” (MIGNOLO, 2003, p.82).

A problemática envolvendo os Direitos Humanos tem sido debatida e discutida, a partir da perspectiva de que, afinal, a diversidade cultural tem sido colocada em contato e, portanto, é necessário verificar parâmetros de diálogos e possibilidades de mútuas inteligibilidades. O que tem prevalecido, contudo, é uma autêntica "epistemologia da cegueira" ou "sociologia das ausências", uma verdadeira produção de não existência em relação a tudo que não cabe na totalidade eurocentrada e no tempo linear: o ignorante, o residual, o inferior, o local e o improdutivo. Como salienta Boaventura de Sousa Santos,

[...] trata-se de formas sociais de inexistência porque as realidades que elas conformam estão apenas presentes como obstáculos em relação às realidades que contam como importantes, sejam elas realidades científicas, avançadas, superiores, globais ou produtivas. São, pois, desqualificadas de totalidades homogêneas, que, como tal, apenas confirmam o que existe e tal como existe. São o que existe sob formas irreversivelmente desqualificadas de existir (SANTOS, 2006, p.104).

Mignolo (2003) salienta que sua crítica é uma crítica não eurocêntrica do eurocentrismo, discutindo a associação entre universalismo e relativismo com a questão colonial e os dualismos "bárbaros/civilizados" e "tradição/modernidade". A Colonialidade do Saber revela que, para além do legado de desigualdade e injustiça sociais profundos do colonialismo e do imperialismo, já 
assinalados pela teoria da dependência e outras, há um legado epistemológico do eurocentrismo que impede de compreender o mundo a partir do próprio mundo em que se vive e das epistemes que lhes são próprias. O fato de os gregos terem inventado o pensamento filosófico, não quer dizer que tenham inventado o pensamento. O pensamento está em todos os lugares onde os diferentes povos e suas culturas se desenvolveram e, assim, são múltiplas as epistemes com seus muitos mundos de vida. Há, assim, uma diversidade epistêmica que comporta todo o patrimônio da humanidade acerca da vida, das águas, da terra, do fogo, do ar, dos seres humanos.

A crítica ao eurocentrismo é uma crítica à sua episteme e à sua lógica que opera por separações sucessivas e reducionismos vários. Espaço e tempo, natureza e sociedade, entre tantas. Há, mesmo nos centros hegemônicos, aqueles que apontam esses limites e a própria ciência natural eurocêntrica revela seu diálogo com o pensamento oriental. Espaço e tempo é cada vez mais espaço/tempo e, nas ciências sociais, essa compreensão não-dicotômica permite ver que modernidade não é algo que surgiu na Europa e que, depois, se expandiria pelo mundo, como se houvesse na geografia mundial um continuum de diferentes tempos, como no seu evolucionismo unilinear.

Entretanto, a Europa só se coloca como centro do Mundo a partir da descoberta da América posto que, até ali, só uma parte marginal da atual Europa, Norte da Itália e seus financistas, se integravam no centro dinâmico comercial do mundo e que os turcos, em 1453, haviam politicamente controlado, quebrando aqueles circuitos. O caminho certo era aquele em direção ao Oriente, portanto, era orientar-se! No Oriente se encontravam as chamadas grandes civilizações, inclusive, com suas religiões tradicionais e o peso da tradição era ali tão forte que, talvez, ajude a compreender o porquê da verdadeira obsessão pelo novo que caracterizará o eurocentrismo e suas sucessivas fugas para frente.

Apesar das informações trazidas por Marco Polo e do extraordinário desenvolvimento científico do mundo chinês, o acesso europeu ao seu conhecimento era limitado, tanto pela distância geográfica quanto pelo desconhecimento do mandarim e outras línguas “orientais". A mentalidade, caracteristicamente, teocêntrica da Europa Cristã medieval trouxe sérios obstáculos à produção de conhecimentos geográficos, além de interromper a divulgação da produção geográfica grecoromana.

Diante desse quadro, a partir do resgate da contribuição greco-romana, de um forte investimento na criação de universidades e de incentivo ao desenvolvimento científico, a geografia produzida pelo Islã medieval tornou-se a principal na escola do pensamento geográfico medieval. Em outros termos, mais sintéticos, o Islã salvou a Geografia (CLAVAL, 2006).

Na Idade Média, os verdadeiros diálogos entre o Islã e o Cristianismo são muito escassos. Somente o Renascimento, com o incremento das relações comerciais entre Ocidente e Oriente vai 
transformar essa situação. Considerando isso, o Islã realizou a ligação (uma espécie de ponte) entre as contribuições geográficas greco-romanas, esquecidas na Europa Cristã medieval, com o Renascimento europeu.

O Islã investiu na produção de um sólido conhecimento geográfico por razões religiosas e econômicas. No primeiro caso, instrumentalizaram-se orientações locacionais para se rezar cotidianamente em direção à Meca, assim planejar peregrinações a essa cidade. No segundo caso, sendo os árabes, fundamentalmente, mercadores, o conhecimento geográfico acompanhou a extraordinária expansão islâmica (LIMA, 2019). Na medida em que se expandia territorialmente o mundo islâmico, aprofundava-se a produção do saber geográfico, e vice-versa.

\section{CONSIDERAÇÕES FINAIS}

Existe um papel extraordinário desenvolvido por Ibn Khaldun na descrição do Ecúmeno, ou seja, a parte habitada da Terra. A expressão ecúmeno deriva de oikos, "a casa", traduz bem a perspectiva tanto regionalista, em torno do Norte da África, ao mesmo tempo em que realiza uma representação árabe-muçulmana do mundo. Em diálogo com o conhecimento greco-romano, Ibn Khaldun não o mimetiza, mas sim o reinventa.

As narrativas khaldunianas prestam uma grande atenção aos modos de vida do Norte da África, contrapondo vida nômade à vida urbana, mas também compreendendo suas correlações.

A tradição da filosofia política ocidental entende a mudança como um processo linear em que o conflito leva todo tempo a um nível mais alto de uma trajetória contínua. No Ocidente, o significado da mudança se tornou um movimento para uma unidade pré-ordenada de pensamento e vida organizada que parecia estar latente na trajetória histórica ocidental (COX, 2000, p. 195).

Mas ainda não foi dito o suficiente sobre o caráter e a qualidade dessas narrativas afroárabe-muçulmanas. Para além de geógrafo, cientista social, historiador, enfim, um polímata, Ibn Khaldun é um humanista do Sul Global.

\section{REFERÊNCIAS}

BISSIO, B. O mundo falava árabe: A Civilização árabe-islâmica clássica através da obra de Ibn Khaldun e Ibn Battuta. Rio de Janeiro: Civilização Brasileira, 2012. 403p.

CLAVAL, P. História da Geografia. Lisboa: Edições 70, 2006. 140p.

COX, R. W. Rumo a uma conceituação pós-hegemônica da ordem mundial: reflexões sobre a relevância de Ibn Khaldun. In: ROSENAU, J. N.; CZEMPIEL, E. O. (Orgs.). Governança sem governo: ordem e transformação na política mundial. São Paulo: Imprensa Oficial do Estado, 2000. p. 210-240. 
HOURANI, A. Uma história dos povos árabes. 2. ed. São Paulo: Cia. das Letras, 2001. 501p.

KHALDUN, I. Os Prolegômenos, ou Filosofia Social. São Paulo: Safady, 1958 - 1960.

LACOSTE, Y. Ibn Khaldun: Nascimento da História. Passado do Terceiro Mundo. São Paulo: Editora Ática, 1991. 254p.

LEME, E. C. S. Considerações Social de Ibn Khaldun (1332-1406). Basilíade: Revista de Filosofia, Curitiba, v. 1, n. 2, p. 37-50, 2019.

LIMA, J. C. O Islã em África: historicidade e geopolítica. Belo Horizonte: Letramento, 2019. $148 \mathrm{p}$.

MIGNOLO, W. D. Histórias locais/projetos globais: colonialidade, saberes subalternos e pensamento liminar. Belo Horizonte: Ed. UFMG, 2003. 505p.

MIGNOLO, W. D. Os esplendores e as misérias da "ciência": colonialidade, geopolítica do conhecimento e pluri-versalidade epistémica. In: SANTOS, B. S. (Org.). Conhecimento prudente para uma vida decente: 'um discurso sobre as ciências' revisitado. São Paulo: Cortez, 2004. p. 667-709.

SAID, E. Orientalismo: o Oriente como invenção do Ocidente. São Paulo: Companhia das Letras, 2007. 480p.

SANTOS, B. S. A gramática do tempo: para uma nova cultura política. 2. ed. São Paulo: Cortez, 2006. 512p.

SENKO, E. C. Ibn Khaldun: vida e trajetória de um historiador islâmico medieval. São Paulo: Ixtlan, 2011. 102p.

SENKO, E. C. Reflexões sobre a escrita e o sentido da História na Muqaddimah de Ibn Khaldun. São Paulo: Ixtlan, 2012. 124p. 